\title{
HUBUNGAN PEMBERIAN ASI EKSKLUSIF DENGAN KEJADIAN DIARE DI PUSKESMAS PULO BRAYAN
}

\author{
Elvalini Warnelis Sinaga ${ }^{1}$, Rahayu Lubis ${ }^{2}$, Zulhaida Lubis ${ }^{3}$ \\ ${ }^{1}$ Peminatan Kesehatan Reproduksi Fakultas Kesehatan Masyarakat Universitas Sumatera Utara \\ Surel: geoffreygopaz@gmail.com \\ ${ }^{2,3}$ Fakultas Kesehatan Masyarakat Universitas Sumatera Utara \\ ABSTRACT
}

Diarrhea is still a public health problem in developing countries such as Indonesia that may prove fatal. Many factors can directly or indirectly be a driving factor for diarrhea, consisting of factors such as agent, host, environment and behavior. Behavioral factors thought to be related to diarrhea include exclusive breastfeeding and child care. The purpose of this study is to analyze the relationship between exclusive breastfeeding and the incidence of diarrhea. This research is an analytic survey with cross sectional approach. The study was conducted at Pulo Brayan civil health center, Medan. The research population was 102 people and all of them were sampled. Data analysis was done using univariate analysis method, bivariate analysis with chi-square with a level of confidence of 95\% ( = 0.05). The result shows that the majority of respondents gave exclusive breastfeeding to their children (55.9\%), did not give exclusive breastfeeding (44.1\%). Children without diarrhea (72.5\%), and children who have diarrhea (27.5\%). The variable of exclusive breastfeeding is related to the incidence of diarrhea in infants aged 6-24 months at the Pulo Brayan civil health center, Medan $(p=0.003<0.05)$. It is recommended for health workers to provide counseling and health education to the community, especially mothers with babies to provide exclusive breastfeeding properly so as to prevent diarrhea.

Keywords: Exclusive breastfeeding, Diarrhea

\begin{abstract}
ABSTRAK
Diare masih merupakan masalah kesehatan masyarakat pada negara-negara berkembang seperti Indonesia yang dapat menyebabkan kematian. Banyak faktor yang secara langsung maupun tidak langsung dapat menjadi faktor pendorong terjadinya diare, terdiri dari faktor agent, penjamu, lingkungan dan perilaku. Faktor perilaku yang diduga berhubungan dengan kerja diare yaitu pemberian ASI eksklusif dan perawatan anak. Tujuan penelitian ini untuk menganalisis hubungan pemberian ASI eksklusif dengan kejadian diare. Penelitian ini adalah survei analitik dengan pendekatan cross sectional. Penelitian dilakukan di Puskesmas Pulo Brayan Medan. Populasi penelitian sebanyak 102 orang dan seluruhnya dijadikan sampel. Analisis data menggunakan analisis univariat, analisis bivariat dengan chi-square dengan tingkat taraf kepercayaan 95\% ( =0,05). Hasil penelitian menunjukkan bahwa sebagian besar responden memberikan ASI eksklusif pada anaknya (55,9\%), tidak memberikan ASI eksklusif (44,1\%). Anak tidak mengalami diare (72,5\%), anak yang mengalami diare (27,5\%). Variabel pemberian ASI eksklusif berhubungan dengan kejadian diare pada bayi usia 6-24 bulan di Puskesmas Pulo Brayan Medan $(p=0,003<0,05)$. Disarankan kepada tenaga kesehatan untuk memberikan penyuluhan dan pendidikan kesehatan kepada masyarakat khususnya ibu yang mempunyai bayi untuk memberikan ASI eksklusif dengan baik sehingga dapat mencegah terjadinya diare.
\end{abstract}

Kata kunci: ASI Eksklusif, Diare

\section{PENDAHULUAN}

\section{Latar Belakang}

World Health Organization (WHO) menyatakan penyakit diare merupakan penyakit tertinggi kedua penyebab kematian pada anak di bawah lima tahun di seluruh dunia setelah penyakit infeksi saluran pernafasan akut (ISPA). Angka kejadian kasus diare di dunia setiap tahunnya mencapai angka 1,7 juta kasus. Setiap tahun diare menyebabkan 760.000 kematian balita di dunia. Berdasarkan data Riset Kesehatan Dasar (Riskesdas) tahun 2013 bahwa insiden dan period prevalence diare untuk seluruh kelompok umur di Indonesia adalah 3,5\% dan 7,0\%. Data Riset Kesehatan Dasar (Riskesdas) tahun 2013 menunjukkan data insiden dan period prevalence diare di Sumatera Utara yaitu 3,3\% dan 6,7\%. Jumlah tersebut masih di bawah insiden dan period prevalence secara nasional sebesar 3,5\% dan 7,0\% (Kemenkes RI, 2013). Hal tersebut harus tetap diwaspadai karena penyakit diare berdampak buruk terhadap kesehatan balita. Bayi 
dan balita lebih berisiko mengalami diare daripada orang dewasa. Golongan usia ini sedikitnya mengalami 2-3episode diare per tahun (Widoyono, 2011). Apabila balita mengalami diare, mereka akan lebih berisiko terkena dehidrasi dan komplikasi lainnya yang dapat mengarah pada malnutrisi hingga terjadi kematian (Christy, 2014). Banyak faktor yang secara langsung maupun tidak langsung menyebabkan terjadinya diare, menjadi faktor agen, penjamu, lingkungan dan perilaku. Faktor penjamu yang menyebabkan meningkatnya kerentanan terhadap diare, tidak memberikan ASI eksklusif, tidak memberikan ASI selama 2 tahun, kurang gizi, penyakit campak, dan imunodefisiensi (Kemenkes RI, 2015). Orang tua berperan besar dalam menentukan penyebab anak terkena diare. Bayi dan anak yang masih menyusui dengan ASI eksklusif umumnya jarang diare karena tidak terkontaminasi dari luar. Puskesmas Pulo Brayan adalah salah satu puskesmas induk yang ada di Kota Medan memberikan berbagai pelayanan kesehatan kepada masyarakat di wilayah kerjanya termasuk pelayanan kepada anak. Salah satu penyakit anak yang ditangani dan dirawat di Puskesmas Pulo Brayan adalah diare dan selalu masuk dalam 10 penyakit terbanyak di Puskesmas Pulo Brayan. Berdasarkan data tahun 2017 tersebut menunjukkan bahwa rata-rata per bulan jumlah balita yang mengalami diare sebanyak 61 balita. Data dari Puskesmas Pulo Brayan menunjukkan bahwa bayi usia 6-24 bulan yang menderita diare sebanyak 203 anak. Survei pendahuluan yang peneliti lakukan di Puskesmas Pulo Brayan Medan dengan mewawancarai 20 orang tua (ibu) memiliki balita penderita diare yang berkunjung ke Puskesmas Pulo Brayan dengan menanyakan tentang pemberian ASI eksklusif dan perawatan yang diberikan pada anaknya sehari-hari. Berdasarkan jawaban ibu bahwa sebanyak 15 orang ibu tidak memberikan ASI eksklusif pada bayinya, dan hanya 5 orang yang memberikan ASI eksklusif. Penelitian ini bertujuan untuk mengetahui hubungan pemberian ASI eksklusif dengan kejadian diare pada anak usia 6-24 bulan di Puskesmas Pulo Brayan Medan tahun 2017.

\section{METODE PENELITIAN}

Penelitian ini merupakan penelitian deskriptif analitik dengan desain potong lintang (cross sectional) yang bertujuan untuk menganalisis hubungan pemberian ASI eksklusif dengan kejadian diare pada anak usia 6-24 bulan. Penelitian ini dilaksanakan di Puskesmas Pulo Brayan Medan di Jln. Yos Sudarso No.136 Pulo Brayan Kota Kecamatan Medan Barat Kota Medan. Populasi penelitian ini adalah ibu yang memiliki anak usia 6-24 bulan bertempat tinggal di wilayah kerja Puskesmas Pulo Brayan Medan dan yang datang berkunjung ke Puskesmas Pulo Brayan Medan sebanyak 1174 orang. Sampel dalam penelitian ini adalah sebagian dari populasi yang besarnya diambil dengan menggunakan rumus Lemeshow (1997) sebagai berikut:

$$
\mathrm{n}=\frac{\left\{Z_{(1-\alpha / 2)} \sqrt{P o(1-P o)}+Z_{(1-\beta)} \sqrt{P a(1-P a)}\right\}^{2}}{(P a-P o)^{2}}
$$

Dimana:

\begin{tabular}{|c|c|c|}
\hline $\mathrm{n}$ & $=$ & Besar sampel \\
\hline $\mathrm{Z}_{(1}$ & & $=$ Deviat baku alpa untuk \\
\hline$Z_{(1}$ & $=$ & Deviat baku beta untuk $=0,10 \rightarrow \mathrm{Z}=1,282$ \\
\hline Po & $=$ & $\begin{array}{l}\text { Proporsi kejadian diare pada balita berdasarkan penelitian Istyaningrum (2010) di } \\
\text { Kelurahan Bendungan Kecamatan Cilegon pada bulan Agustus } 2010 \text { sebesar 37,7\% } \\
(0,377) \text {. }\end{array}$ \\
\hline $\mathrm{Pa}$ & $=$ & Perkiraan proporsi balita yang mengalami diare $(0,277)$. \\
\hline Pa-Po & $=$ & Selisih proporsi sebesar 0,10 (ditetapkan peneliti). \\
\hline
\end{tabular}

Dengan menggunakan rumus di atas, maka diperoleh besar sampel sebagai berikut: 


$$
\begin{aligned}
& \mathrm{n}=\frac{\left\{Z_{(1-\alpha / 2)} \sqrt{P o(1-P o)}+Z_{(1 \beta)} \sqrt{P a(1-P a}\right)}{\}^{2}} \\
& \mathrm{n}=102 \text { orang }
\end{aligned}
$$

Sampel diperoleh sebanyak 102 orang. Data yang digunakan adalah data primer dan sekunder. Data dianalisis menggunakan analisis univariat, dan bivariat dengan uji chi-square pada taraf kepercayaan $95 \%(=0,05)$.

\section{Teknik Pengambilan Data}

Berdasarkan perhitungan di atas diperoleh besar sampel minimal yaitu 102 orang. Penentuan atau penarikan sampel dengan cara aksidental (accidental sampling) yaitu dengan memilih sampel ibu-ibu yang memiliki anak berumur 6-24 bulan yang kebetulan ada atau berkunjung ke Puskesmas Pulo Brayan Medan pada saat peneliti melakukan penelitian.

\section{Metode Penelitian}

Metode analisis data dalam penelitian ini menggunakan langkah-langkah sebagai berikut:

1. Analisis univariat

Analisis univariat yaitu analisis deskriptif untuk mendapatkan gambaran tentang masingmasing variabel independen maupun variabel dependen yang dimasukkan dalam bentuk tabel distribusi frekuensi.

2. Analisis bivariat

Untuk membuktikan adanya hubungan yang signifikan antara variabel bebas dengan variabel terikat digunakan analisis Chi-square, pada batas kemaknaan perhitungan statistik pvalue $(0,05)$. Untuk mengidentifikasi prevalensi faktor risiko, variabel disusun dalam tabel 2x2 kemudian dilakukan penghitungan Prevalence Ratio (PR), yakni perbandingan antara prevalensi kejadian penyakit atau efek pada subjek dari kelompok dengan risiko, dengan prevalensi penyakit atau efek pada subjek pada kelompok tanpa risiko. Rasio prevalensi desain cross-sectional diformulasikan dengan rumus berikut:

$$
\mathrm{PR}=\mathrm{A} /(\mathrm{A}+\mathrm{B}): \mathrm{C} /(\mathrm{C}+\mathrm{D})
$$

$\mathrm{A} /(\mathrm{A}+\mathrm{B})=$ proporsi (prevalensi) subjek dengan faktor risiko yang mengalami efek.

$\mathrm{C} /(\mathrm{C}+\mathrm{D})=$ proporsi (prevalensi) subjek tanpa faktor risiko yang mengalami efek.

\section{HASIL PENELITIAN DAN PEMBAHASAN}

Karakteristik responden yaitu ibu sebagian besar berumur 20-35 tahun (59,8\%), berpendidikan menengah (SMA) (67,6\%), tidak bekerja (ibu rumah tangga) (53,9\%), memiliki 2 orang anak (49,0\%), pendapatan keluarga $\geq$ Rp. 2.528 .815 (60,8\%). Karakteristik anak yaitu sebagian besar anak responden berusia $12-24$ bulan $(52,9 \%)$, berjenis kelamin laki-laki $(55,9 \%)$. Berdasarkan hasil penelitian sebagian besar responden memberikan ASI eksklusif pada anaknya (55,9\%), yang tidak memberikan ASI eksklusif pada anaknya $(44,1 \%)$. Sebagian besar anak tidak mengalami diare $(72,5 \%)$, sedangkan anak yang mengalami diare $(27,5 \%)$.

Hasil uji bivariat menunjukkan bahwa dari 45 anak yang tidak diberi ASI eksklusif mayoritas tidak mengalami diare sebanyak 24 orang (53,3\%). sedangkan dari 57 anak yang mendapatkan ASI eksklusif mayoritas tidak mengalami diare sebanyak 50 orang $(87,7 \%)$. Kejadian diare lebih banyak pada anak yang tidak diberi ASI eksklusif dibandingkan dengan 
anak yang diberi ASI eksklusif. Hasil uji Chi-Square menunjukkan bahwa nilai $p$-value sebesar $0,001<0,05$ artinya terdapat hubungan yang signifikan antara pemberian ASI Eksklusif dengan kejadian diare di Puskesmas Pulo Brayan tahun 2017. Nilai Prevalence Ratio $(P R)=3,800$ artinya yang tidak diberi ASI eksklusif berpeluang menderita diare 3,8 kali lebih tinggi dibandingkan dengan bayi yang diberi ASI eksklusif. Nilai PR $>1$ maka bayi yang tidak beri ASI eksklusif merupakan faktor risiko terjadinya diare.

Tabel 1. Pemberian ASI Eksklusif dengan Kejadian Diare

\begin{tabular}{|c|c|c|c|c|c|c|c|c|}
\hline \multirow{3}{*}{ Pemberian ASI Eksklusif } & \multicolumn{4}{|c|}{ Kejadian Diare } & \multirow{2}{*}{\multicolumn{2}{|c|}{ Jumlah }} & \multirow{3}{*}{ p-value } & \multirow{3}{*}{ PR $(95 \%$ CI $)$} \\
\hline & \multicolumn{2}{|c|}{ Diare } & \multicolumn{2}{|c|}{$\begin{array}{l}\text { Tidak } \\
\text { Diare } \\
\end{array}$} & & & & \\
\hline & Jlh & $\%$ & Jlh & $\%$ & Jlh & $\%$ & & \\
\hline Tidak ASI Eksklusif & 21 & 46,7 & 24 & 53,3 & 45 & 100,0 & \multirow{3}{*}{0,001} & \multirow{3}{*}{$\begin{array}{c}3,800 \\
(1,776-8,133)\end{array}$} \\
\hline ASI Eksklusif & 7 & 12,3 & 50 & 87,7 & 57 & 100,0 & & \\
\hline Total & 28 & 27,5 & 74 & 72,5 & 102 & 100,0 & & \\
\hline
\end{tabular}

\section{Karakteristik Responden}

Karakteristik responden dalam penelitian ini adalah umur, pendidikan, pekerjaan, jumlah anak dan status ekonomi. Berdasarkan umur bahwa sebagian besar responden berumur 20-35 tahun $(59,8 \%)$, berumur $>35$ tahun $(36,3 \%)$, berumur $<20$ tahun $(3,9 \%)$. Responden banyak yang berumur 20-35 tahun karena pada umumnya masyarakat di Indonesia menikah pada usia di atas 20 tahun sehingga ketika memiliki bayi atau balita berada pada rentang usia 20-35 tahun. Responden dengan kelompok umur antara 20-35 tahun masih ada yang memiliki anak sebanyak 1 orang sehingga mereka kurang berpengalaman dalam merawat anaknya sehingga anaknya mengalami diare. Demikian juga pada responden yang berumur $<20$ tahun biasanya menikah pada umur 16-17 tahun sehingga pengalaman dalam melakukan perawatan anak masih minim, selain itu pengetahuan mereka juga masih kurang tentang penyakit diare sehingga anak rentan mengalami diare. Sementara sebagian responden yang berumur 20-35 tahun dan $>35$ tahun sudah berpengalaman dan mengetahui dengan baik dalam merawat anak terutama pencegahan diare sehingga anak dijaga dengan baik agar tidak menderita diare.

Karakteristik berdasarkan pendidikan bahwa responden berpendidikan menengah (SMA) (67,6\%), berpendidikan tinggi (24,5\%), berpendidikan dasar (SD dan SMP) (7,8\%). Hasil tersebut menunjukkan bahwa ibu yang berpendidikan rendah (SD/SMP) di wilayah Puskesmas Pulo Brayan paling sedikit jumlahnya dibandingkan dengan ibu yang berpendidikan menengah dan tinggi. Hal ini karena pemerintah terus menggalakkan peningkatan pendidikan terutama pada wanita hingga minimal berpendidikan menengah (SMA). Tingkat pengetahuan yang baik cenderung dimiliki oleh responden yang berpendidikan tinggi daripada responden yang berpendidikan menengah atau rendah. Hal ini disebabkan, seseorang yang mempunyai latar belakang pendidikan rendah pada umumnya akan kesulitan untuk menyerap ide-ide baru dan membuat mereka lebih konservatif. Karena mereka tidak mengenal alternatif yang terbaik yang tersedia baginya. Sebaliknya orang yang berpendidikan tinggi akan lebih mudah menerima gagasan baru, karena mereka memiliki jalan pikiran yang lebih terbuka untuk menyerap hal-hal baru. Pernyataan ini juga didukung oleh Notoatmodjo (2014) yang mengatakan bahwa pengetahuan dapat diperoleh dari peningkatan pendidikan. McGhie (1996) mengungkapkan bahwa pendidikan bertujuan memperluas pemahaman seseorang tentang dunia di sekelilingnya. Pendidikan tidak hanya sekedar mengenalkan orang pada fakta-fakta baru tapi juga membantu untuk tidak terlalu kaku dalam asumsi dan cara berfikir seseorang. 
Karakteristik berdasarkan pekerjaan bahwa lebih banyak responden tidak bekerja (ibu rumah tangga) $(53,9 \%)$, dibandingkan dengan pekerjaan lainnya seperti pegawai $(22,5 \%)$, pedagang $(16,7 \%)$, dan buruh cuci $(6,9 \%)$. Jumlah responden yang tidak bekerja sebenarnya hampir sama dengan responden yang bekerja di luar rumah seperti pegawai, pedagang, dan buruh cuci yang mencerminkan bahwa setengah dari wanita yang sudah menikah menjadi ibu rumah tangga saja dan setengahnya lagi memiliki untuk bekerja. Responden yang bekerja akan mempunyai peluang untuk memiliki informasi tentang penyakit diare, begitupun pada responden yang tidak bekerja berpeluang sama untuk memiliki pengetahuan yang baik. Hal ini disebabkan, responden yang tidak bekerja akan lebih banyak meluangkan waktunya untuk merawat anak-anaknya dan mencari dan mendapatkan lebih banyak informasi mengenai kesehatan anak. Apalagi saat ini di toko-toko buku banyak dijumpai buku-buku tentang kesehatan anak terutama tentang diare dan cara merawatnya di rumah. Responden yang bekerja, umumnya mempunyai peran ganda yaitu bekerja dan merawat anak.

Karakteristik berdasarkan jumlah anak bahwa responden memiliki 2 orang anak $(49,0 \%)$, memiliki 3 orang anak (23,5\%), memiliki 1 orang anak (20,6\%), dan memiliki 4 orang anak $(6,9 \%)$. Masyarakat perkotaan di wilayah kerja Puskesmas Pulo Brayan pada umumnya sudah mengenal KB dengan baik sehingga mereka telah merencanakan memiliki anak 2 orang saja sesuai dengan program pemerintah. Dengan memiliki 2 orang anak maka mereka diharapkan dapat meningkatkan kesejahteraan keluarga. Pada umumnya anak yang menderita diare adalah keluarga dengan jumlah anak yang banyak, karena perhatian ibu terbagi pada jumlah anaknya yang banyak tersebut sehingga beberapa anak bermain di tempat yang kotor dan menyebabkan kuman masuk dalam tubuh sehingga terjadi diare pada anak tersebut.

Karakteristik berdasarkan pendapatan keluarga bahwa responden dengan penghasilan keluarga di atas UMR $\geq$ Rp. 2.528 .815 (60,8\%), responden dengan pendapatan keluarga $<$ Rp. 2.528 .815 (39,2\%). Lebih banyak responden dengan pendapatan di atas UMR disebabkan pendapatan tersebut adalah gabungan pendapatan suami dan istri yang bekerja, tetapi ada juga memang pendapatan suami sendiri yang memang besar di atas UMR. Pada umumnya pendapatan keluarga yang tinggi membuat keluarga mampu memenuhi kebutuhan gizi keluarga sehingga anak tumbuh sehat dan lingkungan rumah juga bersih dan sehat sehingga dapat mencegah anak menderita diare.

\section{Hubungan Pemberian ASI Eksklusif dengan Kejadian Diare}

Berdasarkan hasil penelitian menunjukkan bahwa terdapat hubungan yang signifikan antara pemberian ASI eksklusif dengan kejadian diare di Puskesmas Pulo Brayan tahun 2017, $\mathrm{p}=0,003$ $<0,05$. Variabel pemberian ASI eksklusif mempunyai nilai $\operatorname{Exp}(B)=4,820$ artinya ibu yang tidak memberikan ASI eksklusif pada bayi berpeluang bayinya menderita diare 4,8 kali lebih tinggi dibandingkan ibu yang memberikan ASI eksklusif pada bayi. Variabel pemberian ASI eksklusif merupakan variabel yang paling besar berhubungan dengan kejadian diare pada bayi usia 6-24 bulan.

Penelitian ini sejalan dengan penelitian Tamimi (2016) di wilayah kerja Puskesmas Nanggalo Kota Padang bahwa berdasarkan uji statistik chi-square menunjukkan bahwa terdapat hubungan antara pemberian ASI eksklusif dengan kejadian diare pada bayi $(p=0,014)$. Penelitian Rahmadhani (2013) di Puskesmas Kuranji Kota Padang dengan judul hubungan pemberian ASI eksklusif dengan angka kejadian diare akut pada bayi usia 6-12 bulan menunjukkan bahwa kejadian diare pada bayi yang mendapat ASI eksklusif sebanyak 9 bayi (26,5\%) dan angka ini 
lebih rendah dibandingkan kejadian diare pada bayi tidak mendapat ASI eksklusif, yaitu 26 bayi (74,3\%). Jumlah bayi yang tidak pernah diare lebih tinggi pada kelompok bayi yang mendapat ASI eksklusif, yaitu 25 bayi $(73,58 \%)$ dibandingkan bayi yang tidak mendapat ASI eksklusif, yaitu 6 bayi $(18,7 \%)$. Berdasarkan data tersebut didapatkan hasil bahwa kejadian diare pada bayi yang tidak mendapat ASI eksklusif lebih tinggi dibandingkan dengan bayi yang mendapat ASI eksklusif. Hasil ini menunjukkan bahwa bayi yang tidak mendapat ASI eksklusif lebih rentan terhadap diare.

WHO menyebutkan pemberian ASI yang tidak eksklusif merupakan salah satu faktor risiko terjadinya diare pada bayi. Penelitian yang dilakukan oleh Quigley et al., (2007) pada sebuah millennium cohort study di Inggris pada anak-anak pasien rawat inap yang menderita diare dan infeksi saluran pernapasan, mendapatkan kesimpulan bahwa pemberian ASI, terutama ASI eksklusif, melindungi anak dari keparahan penyakit yang dideritanya. Penelitian lainnya yang dilaporkan oleh Diallo et al., (2009) membandingkan efek antara ASI eksklusif dan ASI noneksklusif di Conakry, Guinea, hasil yang didapatkan adalah ASI eksklusif secara signifikan melindungi bayi terhadap beberapa penyakit yang diteliti (OR: 0,28, CI: 0,15-0,51) dan khususnya terhadap diare (OR: 0,38, 95\% CI: 0,17-0,86).

Kesimpulan yang sama juga dihasilkan dari penelitian yang dilakukan oleh Abdullah (2012) di Makassar. Jadi, kejadian diare pada bayi dan balita terkait dengan kemampuan seorang ibu dalam pemberian ASI yang tidak memadai kepada bayinya. ASI merupakan minuman alami bagi bayi pada bulan pertama kehidupannya, selain itu ASI juga mengandung nutrisi, antioksidan, hormon dan antibodi yang diperlukan oleh seorang bayi untuk bertahan dan berkembang. Seperti penelitian yang dilakukan oleh Susanty (2012) mendapatkan hasil bahwa terdapat hubungan yang signifikan antara pola pemberian ASI berdasarkan frekuensi menyusui sehari dengan kejadian gizi buruk dan merupakan faktor risiko.

Diare merupakan salah satu penyebab mortalitas pada bayi di negara berkembang. Tingginya kejadian diare dipengaruhi berbagai faktor, salah satunya adalah tidak dilakukannya pemberian ASI. Efek proteksi ASI lebih optimal jika diberikan secara eksklusif. ASI merupakan suatu emulsi lemak dalam larutan protein laktose dan garam-garam organik yang disekresi oleh kedua belah payudara ibu sebagai makanan utama bagi bayi, ASI menurut stadium laktasi terdiri dari kolostrum, ASI transisi, dan ASI matur. ASI memberikan imunitas atau kekebalan yang belum dapat dibuat sendiri oleh bayi yang baru lahir (Soetjiningsih, 2014).

Menurut peneliti, hasil penelitian ini membuktikan bahwa bayi yang diberi ASI eksklusif cenderung tidak mengalami diare dibandingkan bayi yang tidak diberi ASI eksklusif oleh ibu pada usia 0-6 bulan. Bayi yang tidak diberi ASI eksklusif telah diberi makanan tambahan sejak dini, ada yang diberi makanan sejak umur 1 minggu, 2 minggu, 3 minggu, dan ada juga yang diberi pada bayi usia 1 bulan dengan berbagai macam alasan seperti ASI tidak cukup, kasihan bayinya karena sudah semakin besar kalau hanya diberi ASI tidak kenyang. Ada juga yang beranggapan bahwa dulu ibu dan neneknya memberi makanan pada bayi sejak bayi berumur 1 minggu dan terbukti ia sehat-sehat saja sampai saat ini, jadi ia berpandangan bahwa bayi harus diberi makan sejak berumur 1 minggu. Kalau anaknya saat ini diare menurut mereka bukan karena tidak diberi ASI eksklusif tetapi karena faktor lain seperti anak termakan makanan kotor (misalnya makanan yang sudah jatuh di tanah, diambil dan dimakan oleh bayi). Mereka berpandangan bahwa anak tetangganya pun yang hanya diberi ASI eksklusif mengalami diare. Pandangan keliru tersebut mempengaruhi pengetahuan dan pemahaman mereka tentang 
pentingnya pemberian ASI eksklusif pada bayi sejak lahir sampai usia 6 bulan, bahwa ASI eksklusif dapat memberikan imunitas pada bayi sehingga bayi tidak mudah terserang penyakit seperti diare.

\section{KESIMPULAN DAN SARAN}

\section{Kesimpulan}

Responden memberikan ASI eksklusif pada anaknya (55,9\%), yang tidak memberikan ASI eksklusif pada anaknya (44,1\%). Sebagian besar anak tidak mengalami diare (72,5\%), sedangkan anak yang mengalami diare $(27,5 \%)$. Terdapat hubungan yang signifikan antara pemberian ASI Eksklusif dengan kejadian diare di Puskesmas Pulo Brayan tahun 2017, $(\mathrm{p}=0,001<0,05)$. Bayi yang tidak diberi ASI eksklusif berpeluang menderita diare 3,8 kali lebih tinggi dibandingkan dengan bayi yang diberi ASI eksklusif. Nilai PR $>1$ maka bayi yang tidak beri ASI eksklusif merupakan faktor risiko terjadinya diare.

\section{Saran}

1. Disarankan kepada Kepala Puskesmas Pulo Brayan Medan untuk melakukan promosi kesehatan tentang pencegahan penyakit diare pada balita dan meningkatkan cakupan ASI eksklusif di wilayah kerja Puskesmas Pulo Brayan Medan sehingga dapat menurunkan angka kejadian diare pada anak.

2. Disarankan pada ibu yang selalu mendampingi dan merawat anakagar memberikan anak ASI eksklusif sejak lahir sampai umur 6 bulan dan memberikan perawatan yang terbaik pada anaknya serta selalu memperhatikan kondisi anaknya jika mengalami tanda dan gejala diare segera memberi pertolongan secepatnya.

\section{REFERENSI}

Abdullah, A. Z., Arsin, A. A., \& Dahlan, L. 2012. Faktor risiko diare shigellosis pada anak balita. Kesmas. Jurnal Kesehatan Masyarakat Nasional, 7 :1, 16-21.

Diallo, F.B., Bell, L., Moutquin, J.M., \& Garant, M.P. 2009. The effects of exclusive versus nonexclusive breastfeeding on spesific infant morbidities in Conakry. Pan African Medical Journal.

Ehlayel M.S., Bener A., Abdulrahman H.M., 2009. Protective Effect of Breastfeeding on Diarrhea among Children in a Rapidly Growing Newly Develop Society. The Turkish Journal of Pediatrics. 51: 527-33.

Goldman RD, Friedman JN, and Parkin PC. 2014. Validation of the Clinical Dehydration Scale for Children with Acute Gastroenteritis. Pediatrics. 2014; 122(3): 545- 549.

Gupte S. 2013. Panduan Perawatan Anak. Cetakan Pertama. Jakarta: Pustaka Populer Obor.

Kemenkes RI. 2013. Riset Kesehatan Dasar Tahun 2013. Jakarta: Kementerian Kesehatan Republik Indonesia.

Kemenkes RI. 2015. Manajemen Laktasi. Buku Panduan bagi Bidan dan Tenaga Kesehatan di Puskesmas. Jakarta: Kementerian Kesehatan Republik Indonesia.

Lely. 2011. Peran ASI Eksklusif yang Mengandung Antibodi SIgA terhadap Risiko Diare Akut pada Bayi Usia 1-6 Bulan. Denpasar: Universitas Udayana.

Notoatmodjo, S. 2014. Promosi kesehatan dan Perilaku Kesehatan. Jakarta: Rineka Cipta

Prasetyono, D.S. 2015. ASI Eksklusif Pengenalan, Praktik dan Kemanfaatan-kemanfaatannya. Yogyakarta: Diva Press.

Quigley, M.A., Kelly, Y.J., \& Sacker, A. 2007. Breastfeeding and Hospitalization for Diarrheal and Respiratory Infection in the United Kingdom Millennium Cohort Study. Pediatrics, 119; e837.

Rahmadhani, E.P. 2013. Hubungan Pemberian ASI Eksklusif dengan Angka Kejadian Diare Akut pada Bayi Usia 0-1 Tahun di Puskesmas Kuranji Kota Padang. Jurnal Kesehatan Andalas. 2013; 2(2).

Soebagyo, B. 2013. Diare Akut pada Anak. Surakarta: Sebelas Maret University Press. 
Soenarto Y, Aman AT, Bakri A, Waluyo H, Firmansyah A, Kadim M. 2013. Burden of Severe Rotavirus Diarrhea in Indonesia. Jakarta: JID.

Suradi, R. 2012. Air Susu Ibu. Dalam: Markum, A.H., Buku Ajar Ilmu Kesehatan Anak Jilid I. Fakultas Kedokteran Universitas Indonesia. Jakarta: Balai Penerbit Fakultas Kedokteran Universitas Indonesia.

Susanty, M., Kartika, M., Hadju, V., \& Alharini, S. 2012. Hubungan pola pemberian ASI dan MP-ASI dengan gizi buruk pada anak 6-24 bulan di Kelurahan Pannampu Makassar. Media gizi masyarakat indonesia, 97-103.

Tamimi, R.A. 2016. Hubungan Pemberian ASI Eksklusif Dengan Kejadian Diare Pada Bayi Di Wilayah Puskesmas Nanggalo Padang. Jurnal Kesehatan Andalas. 2016; 5(1).

Triasmara, W. 2013. Cara Agar Balita Tidak Mudah Sakit. Jakarta: Gramedia Pustaka Utama.

Widjaja. M.C. 2012. Mengatasi Diare dan Keracunan pada Balita. Jakarta: Kawan Pustaka

Widoyono. 2011. Penyakit Tropis: Epidemiologi, Penularan, Pencegahan \& Pemberantasannya. Edisi Kedua. Jakarta: Erlangga. 